\title{
Systematic learning in water governance: insights from five local adaptive management projects for water quality innovation
}

\author{
Elisa Kochskämper $^{1,2}$, Tomas M. Koontz ${ }^{3}$ and Jens Newig ${ }^{1}$
}

\begin{abstract}
Adaptive management has been proliferating since the 1970s as a policy approach for dealing with uncertainty in environmental governance through learning. Learning takes place through a cyclical approach of experimentation and (possible) adjustment. However, few empirical studies exist that cover full iterations of adaptive management cycles. We report on five adaptive management projects on water quality enhancement, of which four led to innovations in the small-scale management of waterways in northern Germany. We trace processes as well as outcomes, to identify factors affecting learning, environmental improvement, and the successful delivery of a project throughout a management cycle.

Our findings point to a key difference between two kinds of uncertainty in the studied processes: ecological uncertainty (whether and how interventions will be effective in improving water quality) and what we term "social uncertainty" (how stakeholders will respond to interventions). We find that those managers performed better who addressed both kinds of uncertainty. Factors for dealing with social uncertainties were usually rather different than the ones linked to knowledge gain for the results in the rivers, and their acknowledgment was decisive for successful project delivery. On a conceptual level, our findings suggest that the model of a dual feedback cycle, including both types of uncertainties, allows for more clear-cut conceptual differentiation and empirical outcome measurement of adaptive management processes.
\end{abstract}

Key Words: comparative research; environmental governance; implementation; public participation; Water Framework Directive

\section{INTRODUCTION}

Achieving sustainable water governance is a prime example of complex environmental problems that face humanity. In recent years, scholars and practitioners have called for a transformation in how we address such problems because current governance arrangements are not sufficient (see, e.g., Blackmore et al. 2016).

Adaptive management (AM) is praised as an approach to solve complex problems (Armitage et al. 2009), deal with uncertainty (Walters 1997, Gunderson 1999), improve resilience (Folke et al. 2005), and advance governance of natural resource systems in general (Fabricius and Cundill 2014). The main tenet of AM conveys its intuitively appealing logic: learning and subsequent adaptation of management (Allen and Garmistani 2015) through continuous testing, monitoring, evaluating, and adjusting of policy options within a cyclical approach (Holling 1978, Walters 1986). Despite its allure, and while research on AM abounds, scholars have voiced several concerns with how the field develops. First, the concept is used in a very broad sense (Allen et al. 2011), and conceptual clarity of learning itself is lacking (Fabricius and Cundill 2014). In addition, scholars are skeptical about the applicability of the experimental approach to a range of natural resource field settings (Gregory et al. 2006, Rist et al. 2013). Finally, few empirical studies exist on full iterations of AM cycles (Chaffin and Gosnell 2015; see Allan and Stankey 2009 as a notable exception) or reporting on actual implementation (Keith et al. 2011, McFadden et al. 2011).

With this article we aim to explore the potential of AM for environmental improvements and learning, stressing two types of uncertainties (ecological and social) that the experimental approach encounters. We examine five German cases of small- scale AM projects that tested innovative measures in water quality enhancement.

\section{ADAPTIVE MANAGEMENT: UNRAVELING A CONCEPT}

\section{Origin, content, and growth of the approach}

Grounded in Holling's studies on ecosystem functioning in the 1970s (see Holling 1978), AM acknowledges nature as a dynamic and complex system that is difficult, if not impossible, to predict because of our incomplete and uncertain knowledge (de Groot and Lenders 2006, Pahl-Wostl et al. 2008, Foxon et al. 2009). Through a combination of trial and error and scientific learning (Meffe et al. 2002), AM aims to close knowledge gaps by uncovering how management interventions will in fact work; e.g., how do different regulated flow regimes from dam operations affect water quality, sediment loads, and fish populations (Lee 1993, Pulwarty and Melis 2001)? To do so, the AM approach involves designing and employing management actions in the form of experiments within a cyclical process (Walters and Holling 1990, Folke et al. 2005; see Fig. 1): First, management problems are defined and potential solutions formulated, and subsequently existing knowledge is synthesized to identify key knowledge gaps of the (sub)system of interest, leading to the design of management actions; afterward these actions are implemented and monitored to generate data for evaluation, which allows managers to learn about the actions' impact and (if necessary) to adjust them; and then add the gained understanding to the knowledge base (Meffe et al. 2002, Gunderson 2015). Through learning from these experiments and adaptation of practices, the approach is claimed to instruct more effective natural resource management (Medema et al. 2008, Allen and Garmistani 2015).

${ }^{1}$ Working group Governance and Sustainability, Leuphana University Lüneburg, Germany, ${ }^{2}$ Research Department Institutional Change and Regional Public Goods, Leibniz Institute for Research on Society and Space, Erkner, Germany, ${ }^{3}$ School of Interdisciplinary Arts and Sciences, University of Washington Tacoma 
Fig. 1. The adaptive management cycle (adapted from Chaffin and Gosnell 2015)

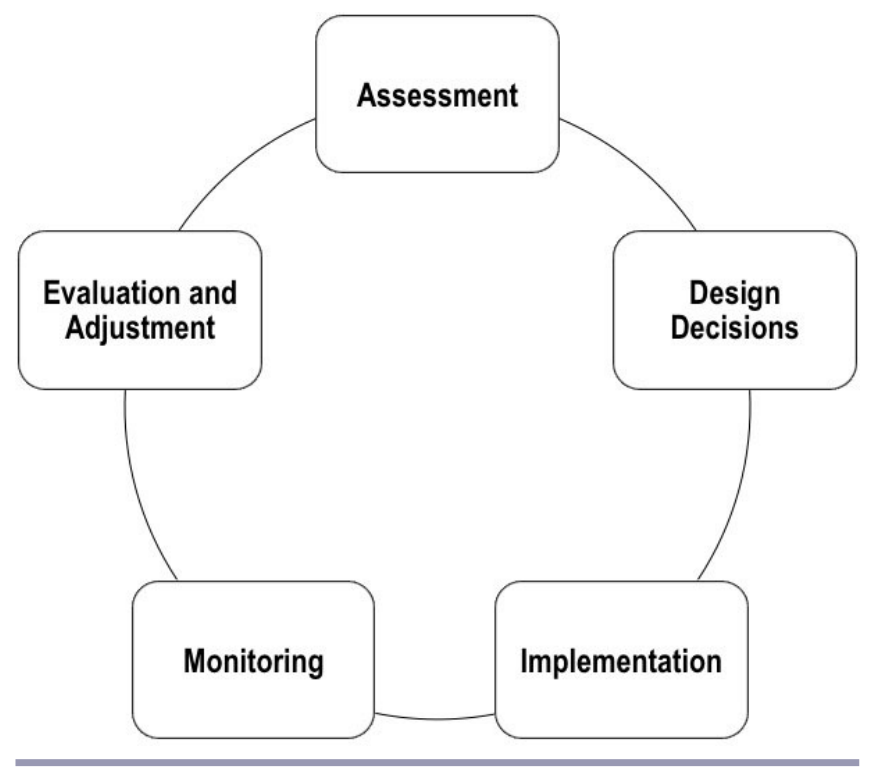

The notion of addressing incomplete knowledge and uncertainty through learning has made its way into related environmental management approaches. The main examples in this regard are participatory and collaborative approaches, which stress that different knowledge types (not only scientific knowledge) are needed for a solid knowledge base to tackle uncertainty and foster learning (Pahl-Wostl et al. 2007, Armitage et al. 2009, Plummer et al. 2012). To highlight the collaborative element, this concept was labeled adaptive comanagement (Plummer 2009). Similarly, polycentricity scholars conceptualized an adaptive institutional system having multiple centers or units of power providing redundancy and opportunities for units to learn from each other (Huitema et al. 2009, Chaffin et al. 2014). In addition, scholarship on social-ecological systems and resilience developed the concept of adaptive governance, which emphasizes dynamic learning through multilevel, polycentric, and collaborative characteristics of comanagement (Walker et al. 2004, Folke et al. 2005, Folke 2006). Both adaptive comanagement and adaptive governance address the expansion, operationalization, and scaling of AM and are frequently used synonymously (Chaffin et al. 2014).

These conceptual amplifications highlight the promising appeal of AM. At the same time, the body of literature on failures of $\mathrm{AM}$ and specific barriers to its implementation is growing (Rist et al. 2013, Allan and Watts 2018). It has not yet been shown whether failures or barriers are attributable to the method itself or exogenous factors, such as unfeasible contexts for application, generic obstacles for management implementation, inappropriate expectations, and under-reporting of success (Rist et al. 2013, Allan and Watts 2018). One major difficulty to disentangle this is the missing consensus on measuring success: According to Rist et al. (2013) the main goal of AM is the reduction of uncertainty surrounding an environmental problem; Chaffin and Gosnell (2015) put emphasis on a sound process for successful management, whereas Fabricius and Cundill (2014) as well as
Allan and Watts (2018) propose the occurred learning as the key success outcome. However, who learns what and how is understood very differently (Fabricius and Cundill 2014, Allan and Watts 2018). Therefore we dissect the outcome-side of AM and define success criteria.

\section{Measuring success in adaptive management}

AM acknowledges that "systems to be managed are, in broad terms, complex, unpredictable, and characterized by unexpected responses to intervention" (Pahl-Wostl et al. 2007). Learning in $\mathrm{AM}$ is therefore deliberate and result oriented (Hillmann 2009) by integrating uncertainty into a decision-making framework, and reducing it through management (Williams and Brown 2016). Uncertainty in AM "arises from imperfect information about system response" (Keith et al. 2011:1175). Environmental resource managers anticipate cause-and-effect relations between actions and ecological components. Rist et al. (2013) call this "ecological uncertainty." The possible adjustment of management actions allows for various iterations of the feedback cycle, thereby narrowing this uncertainty until the anticipated environmental improvement is achieved, thereby refining future management (Williams and Brown 2014; see Fig. 2). Improved environmental conditions are ingrained into the learning endeavor and one successful outcome of AM. Although the identification and reduction of uncertainty is key in AM (Allen et al. 2011), Walters (1986) stresses that it is not possible to completely reduce uncertainty. There are simply indeterminable and irreducible sources of uncertainty, i.e., when objective probabilities cannot be assigned to potential outcomes (Tyre and Michaels 2011).

Fig. 2. Success in adaptive management projects in relation to ecological and social uncertainty.

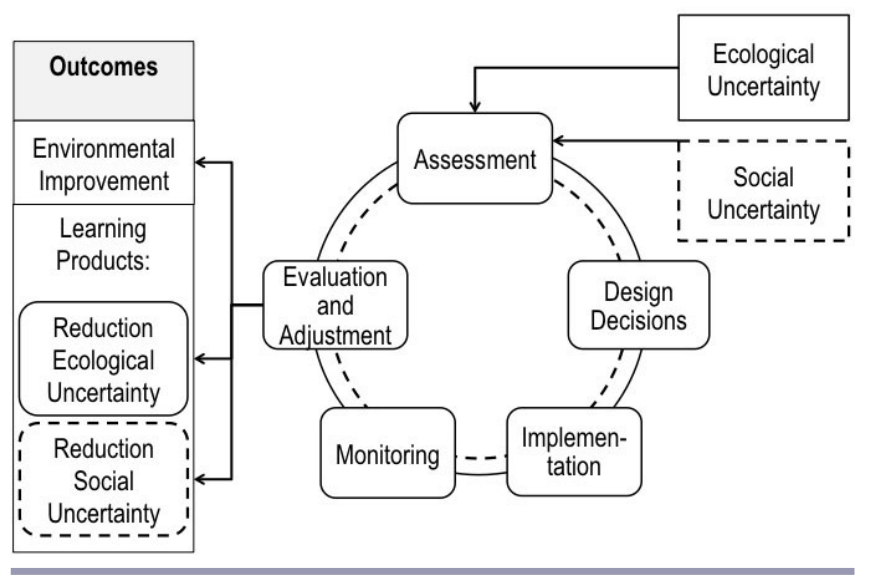

This indeterminism is even more accentuated when it comes to socially induced uncertainties (Tyre and Michaels 2011). Interdependent social-ecological uncertainty describes an inherent property of systems defined by human-environment interaction and related management (Armitage et al. 2008). First, socially induced uncertainties can stem from different beliefs about reality or differing subjective probabilities assigned to an event by individuals (Tyre and Michaels 2011). Second, AM implies experimentation in the real-world context with consequences of actions for affected stakeholders, which can lead 
to "the questioning of who has the knowledge and capacity to manage" (Jacobson et al. 2009:485). Rist et al. (2013) highlight the importance of a feasible social, political, and institutional context to allow managers to implement different management actions. Lee (1993, 1999) as well as Voß and Bornemann (2011) point to conflict and political struggle as being integral to or unavoidable in the experimental approach.

We follow Tyre and Michaels (2011) in their call to distinguish ecologically and socially induced uncertainty, and define social uncertainty as the potential unanticipated response from people in the social system to an AM intervention. A collaborative decision-making structure prior to experimentation might prevent unbounded conflict (Lee 1999), however, there is no guarantee that stakeholders will agree on results, or that unforeseen surprises such as shifting objectives in management regimes will not occur (Tyre and Michaels 2011). Again, a complete reduction of social uncertainty is out of reach, yet learning about social factors affecting how stakeholders respond to interventions is crucial for AM to be understood as not overly mechanistic or technical. This learning is often left out in AM literature (Pahl-Wostl 2009, Williams and Brown 2014, 2016). Of course other components influence social uncertainty in managing social-ecological systems, e.g., processes of individual and group identity building that affect individuals' behavior and perceptions. The AM literature, when mentioning social uncertainty, typically focuses on how stakeholders respond to experiments (Lee 1993). Therefore, as a first step in bringing social science more fully into AM, in this study our data on social uncertainty depict how stakeholders responded to experiments.

We understand the learning outcome in AM to be reduction of ecological and social uncertainty. When both ecological learning and social learning are achieved, opportunities for double-loop learning conducive to innovation emerge (Williams and Brown 2014). Double-loop learning leads to reflection on questions underlying values, beliefs, or the status quo and explores innovative approaches. This contrasts with single-loop learning, which refers to instrumental changes without overhauling belief or value systems and management regimes (Argyris and Schön 1978, 1996, Pahl-Wostl et al. 2007, Fabricius and Cundill 2014).

Apart from what is being learned, it is crucial to define who learns. Early work entirely focused on individual learning by scientists and resource managers (Holling 1978, Walters 1986, Foxon et al. 2009, Fabricius and Cundill 2014). Lee (1993) expanded this view to organizational and social learning, including stakeholders. Gunderson and Holling (2002) also acknowledge that it is not sufficient for the project's resource managers alone to learn. Learning by stakeholders or societal actors can lead to acceptance of outcomes as well as the spreading of AM successes (Graham and Hicks 2015), which is in line with general assumptions of participatory environmental governance (Newig et al. 2018). Although ecological learning relates to managers and stakeholders, we see the learning about social uncertainties mainly linked to organizers or managers of AM.

\section{Factors influencing successful adaptive management}

Literature on AM offers an abundant set of factors that are expected to impact the success of projects. In order to provide structure, we assign these factors to the individual management phases as conditions that might impact each type of uncertainty in potentially reducing the unanticipated response by the ecological and/or social (sub)system of interest (see Table 1).

Table 1. Factors for reducing uncertainties in AM projects, aligned with types of uncertainty and management phases.

\begin{tabular}{lll}
\hline \hline $\begin{array}{l}\text { Phase of Adaptive } \\
\text { Management }\end{array}$ & Ecological Uncertainty & Social Uncertainty \\
\hline $\begin{array}{l}\text { Assessment/ } \\
\text { Design decisions }\end{array}$ & $\begin{array}{l}\text { Local scale } \\
\text { Rigorous design } \\
\text { Knowledge } \\
\text { incorporation }\end{array}$ & $\begin{array}{l}\text { Enabling legislation } \\
\text { Communication } \\
\text { Reversibility }\end{array}$ \\
Implementation & Networks & Bridging organizations \\
Monitoring & Long-term monitoring & Trust \\
& $\begin{array}{l}\text { Participatory } \\
\text { monitoring }\end{array}$ & Sufficient budget \\
& Possibility for & Documented, \\
Evaluation and & communicated effects \\
\hline adjustment & &
\end{tabular}

At the outset of an AM project is the assessment/design decisions phase, where management problems are defined and potential solutions formulated before existing knowledge is synthesized to identify knowledge gaps. Here a local scale for testing is recommended to enhance predictability of ecological cause-andeffect chains (Cook et al. 2004, Chaffin and Gosnell 2015, Murray et al. 2015). AM blends scientific rigor with practicality (Meffe et al. 2002), which leads to different project designs: passive AM, documented trial and error learning, and active AM. The latter uses rigorous experimentation with hypotheses and controls to structure learning, arguably making it more effective (Meffe et al. 2002, Allen and Garmestani 2015, Gunderson 2015). The emphasis on a rigorous design links back to the origins of AM seen as navigated by scientific and expert knowledge as a science inquiry process based on models, simulations, and deduction (Holling 1978, Walters 1986, Foxon et al. 2009, Fabricius and Cundill 2014, Gunderson 2015). The adaptive learning process is similar to organizational learning, which entails the integration of new, viable, and effective insights and findings into organizational or institutional structures (Thomas and Allen 2006). In principle, it does not matter how these are discovered. Adaptive comanagement and governance scholars draw on participation for the inclusion of complementing knowledge. This idea has also made its way into AM literature (Stringer et al. 2006, see also Fabricius and Cundill 2014 on this). To reflect both views, knowledge incorporation to reduce ecological uncertainty can occur through the elicitation of expert knowledge or the integration of different knowledge types.

As already mentioned, stakeholder involvement is also seen as key in preventing conflict and in building a shared understanding of the objectives and the management process (Lee 1999, Chaffin and Gosnell 2015). Thus, communication pertains to this component of social uncertainty, which can take the form of oneway information or two-way exchange, including dialogue or deliberation as an equal exchange of arguments (see, e.g., Newig et. al 2018). AM can allow managers to identify the most viable way to achieve agreed upon outcomes, and to clarify trade-offs within different options, but is not per se a conflict resolution strategy, particularly when it comes to conflicts of values over desired outcomes (Murray et al. 2015). The reversibility of interventions and treatment responses is seen as an additional 
strategy to prevent conflict (Murray et al. 2015). Further, bridging organizations are supposed to function as intermediaries between agencies and projects on the ground (Hahn et al. 2006, Plummer et al. 2012, Allen and Garmistani 2015). Considering the immanent political dynamics and path-dependencies in policy planning and management (Voß and Bornemann 2011), a legal context that does not hinder (Murray et al. 2015) or even support AM (Allen and Garmestani 2015) embodies a prerequisite within the social system for realistic planning of management interventions.

Once the project design is complete, AM moves to the implementation phase, in which experiments are applied. In line with the process of organizational learning, new knowledge brought in is seen as ongoing in AM (Walters 1986). Regarding policy experiments, McFadgen and Huitema (2017) distinguish between the ideal types of technocratic and boundary experiment: the former is issued by policy actors to experts for instrumental problem solving through (assumedly) objective knowledge independent of context and subjects; the latter is inclusive by involving stakeholders to produce evidence and develop shared values based on multiple knowledge types. For participatory forms of AM, networks in which individuals, e.g., managers, stakeholders, or public officials, interact are thought to stimulate learning through enhanced information flow and exchange (Plummer et al. 2012, Fabricius and Currie 2015, Koontz et al. 2015). They can also operate as science-management-policy networks fostering the implementation of best available science through stakeholders (Chaffin and Gosnell 2015, Berkley and Gunderson 2015). Therefore we see them as mainly helping to reduce ecological uncertainty. For a smooth functioning and reduction of sudden disruptions or conflicts, trust is vital between managers and stakeholders, which is perceived in general as catalyzing AM projects (Gunderson 1999, 2015, Hahn et al. 2006) and thus placed into the category of factors reducing social uncertainty about how stakeholders will respond to interventions.

Monitoring, which follows the implementation phase, is critical for AM because it provides feedback on management experiments (Aceves-Bueno et al. 2015, Gunderson 2015, Holling and Sundstrom 2015). A system should be in place that secures minimum quality of and consistency standards for data, so that changes can be clearly attributed to interventions, and unintended consequences can be quantified (Aceves-Bueno et al. 2015, Waylen and Blackstock 2017). Persistent, long-term monitoring supports sound and useful data collection to reduce ecological uncertainty (Koontz and Thomas 2006, Holling and Sundstrom 2015). Additionally, participatory monitoring is increasingly recommended for integrating different knowledge types to reduce ecological uncertainty (Aceves-Bueno et al. 2015, Waylen and Blackstock 2017). The lack of financial resources can disrupt the AM cycle particularly during this phase (Butler and Koontz 2005, Aceves-Bueno et al. 2015, Williams and Browns 2016, Waylen and Blackstock 2017). Costs for monitoring are more challenging than in other management approaches, thus a sufficient budget is crucial. In addition, leadership (organizational or individual) is seen as a key factor for the successful delivery of AM (Plummer et al. 2012, Gunderson 2015, Koontz et al. 2015, Murray et al. 2015) and is especially important during this critical phase.
The final phase is evaluation and (potential) adjustment. The possibility of adjustment is the main feature in AM to reduce ecological uncertainty. Documentation and communication of effects support the proper use of results in the future, thereby addressing social uncertainty. In a survey of 70 river enhancement projects, O'Donnell and Galat (2008) found that lack of documentation and accessibility to project information, especially project monitoring, are notable obstacles for conducting AM.

\section{CASE SELECTION AND METHODOLOGY}

Data for this comparative case study come from five AM projects conducted as part of the implementation of the European Water Framework Directive (WFD, Directive 2000/60/EC). The WFD is arguably the single most important piece of recent European legislation in water governance (Hering et al. 2010), stipulating action conducive to cleaner waters throughout the European Union (EU). The main categories of action are restoring the natural river flow and reducing pollution. Up until now, EU Member States have focused mainly on improving river connectivity, by removing disruptive infrastructure (Kochskämper et. al. 2017). In addition, innovative small-scale approaches targeting mainly diffuse source pollution from, for example, nitrate and renaturalization, have emerged. These approaches include pilot projects that test new types of actions for water quality improvement. For this study, an AM case is a project that aims at learning about replicable actions, following an experimental approach.

We selected five such cases in Germany, two in SchleswigHolstein, the most northern federal state, and three in the adjacent city state of Hamburg. Thus, all cases were embedded in a similar climatic, cultural, and legal context. The WFD required a status assessment of all EU water bodies that had to be made publicly available. The assessment revealed poor water quality in the states of Hamburg and Schleswig-Holstein. The cases share the same pursuit, namely water quality enhancement (see Table 2): three of them through in-stream modifications, i.e., installing gravel, deadwood, or similar material into river stretches to improve dynamic meandering in the water flow (Case 1, 3, 5), one through changes in riparian vegetation and waterway management to improve water quality without reducing run-off too far (Case 2), and one through reintroducing different water plants with a cleaning function for rivers (Case 4). The similar case context comes close to a "most similar" case design (Gerring 2007).

We engage in an exploratory qualitative within-case inference and cross-case comparison. The first author held interviews between 2015 and 2017 with the main managers of all projects $(\mathrm{N}=7)$, and examined case material documents for data triangulation. Documented material included meeting minutes, reports, funding requests, memoranda of agreement, and newspaper articles totaling nearly 1000 pages. Interviews were conducted using a semistructured format following Lamnek (1989) based on the conceptual basis presented, asking for the project course and outcomes. They lasted between 45 and 90 minutes each and were conducted in person. The interviews were conducted in German by a native German speaker fluent in English, who translated them for this article. We performed a content analysis on the transcribed interviews and documentary case material. Following 
Table 2. Features of case studies.

\begin{tabular}{|c|c|c|c|c|c|}
\hline Design Factors & $\begin{array}{c}\text { Case 1: } \\
\text { In-stream } \\
\text { modification }\end{array}$ & $\begin{array}{c}\text { Case 2: } \\
\text { Riparian vegetation }\end{array}$ & $\begin{array}{c}\text { Case 3: } \\
\text { In-stream } \\
\text { modification }\end{array}$ & $\begin{array}{c}\text { Case 4: } \\
\text { Reintroduction water } \\
\text { plants }\end{array}$ & $\begin{array}{c}\text { Case 5: } \\
\text { In-stream modification }\end{array}$ \\
\hline Project initiator & District agency & Environment agency & University & ENGO & ENGOs (3) \\
\hline Running time & $2013-2015$ & $\begin{array}{l}\text { First } 2009 \text { to } 2013 \text {; then to } \\
\qquad 2017\end{array}$ & 2008 to 2014 & $\begin{array}{l}2010 \text { to } 2014 \text {; additional } \\
\text { monitoring } 2017\end{array}$ & 2009 to 2017 \\
\hline Bridging organization & $\begin{array}{l}\text { Environmental } \\
\text { planning bureau }\end{array}$ & Biologist team & & & \\
\hline Funding & \multicolumn{5}{|c|}{ Environment agencies of Hamburg or Schleswig-Holstein } \\
\hline Legal context & \multicolumn{5}{|c|}{ EU Water Framework Directive (WFD) } \\
\hline Scale & \multicolumn{5}{|c|}{ Local scale } \\
\hline Reversibility & \multicolumn{5}{|c|}{ High } \\
\hline
\end{tabular}

Miles and Huberman (1994), the content was coded based on the different management phases and related enabling factors as well as potential outcomes defined as measures of success above. The coding was performed in a deductive way, based on prior literature, identifying the presence or absence of factors and outcomes in the case material to trace trajectories for each case. Below interviews are cited with a case code according to the case number, and interview quotes are used as representative examples for this coding procedure.

It is important to note that, according to McFadgen and Huitema's (2017) terminology, Cases 1 to 4 were planned as technocratic and only Case 5 as a boundary experiment with stakeholder involvement planned from the outset. Technocratic experiments include the problem definition and determination of solutions to be tested by (policy) actors in advance. In Case 1 a district agency in Hamburg contacted an environmental planning bureau to test in-stream modifications in a river suffering from particularly high pollution levels. In Case 2 the environmental agency of Schleswig-Holstein contacted a biologist team to test altered riparian vegetation in different rivers throughout the federal state. In both cases these contacted experts acted as bridging organizations because the experiments had to be communicated to stakeholders. Nonstate actors initiated the remaining projects: In Case 3 a university proposed in-stream modifications in a larger renaturalization project to the environmental agency of Schleswig-Holstein for funding, and to the water board, an association mainly comprising landowners, overseeing a certain catchment for coimplementation. In Cases 4 and 5, environmental nonstate organizations (ENGOs) perceived a window of opportunity through WFD implementation and obtained funding from Hamburg's environmental agency. In Case 4 , the botanic association noticed through the water status assessment that in $80 \%$ of Hamburg's rivers water plants were missing (I:C4). In Case 5, the local branches of three major German ENGOs observed the district agencies' main focus on improved river connectivity for WFD implementation (I1:C5). This allowed them, under the lead of one ENGO, to step in for additional small-scale actions targeting pollution, particularly instream modifications, in the River Alster, which crosses the whole city (I1:C5). In all cases interventions could be easily reversed through a removal of installed material, riparian vegetation or water plants. Apart from water plants, slight negative effects for stakeholders, e.g., landowners or farmers, were possible, such as erosion or reduced water run-off.

\section{LOCAL APPLICATION OF FIVE ADAPTIVE MANAGEMENT PROJECTS FOR WATER QUALITY IMPROVEMENT}

\section{Assessment and design decisions}

In all of the cases the problem definition and determination of actions to be tested was already established in advance, although the ENGO in Case 5 provided the possibility to bring in further proposals through deliberative workshops. Knowledge about the ecological effects of particular interventions varied across the cases. Actors in Hamburg (Cases 1 and 5) already had experience with in-stream modifications, while managers in SchleswigHolstein (Case 3) were inexperienced ("There was no manual") and their river was one of the first test sites for this type of action in the federal state (I:C3). Knowledge about effective altered water maintenance (Case 2) and in particular water plants (Case 4) was almost nonexistent (I:C1; I:C4). Figure 3 shows the presence of particular factors in each case trajectory.

In Case 1 managers relied on expert knowledge for modeling flow dynamics, and they developed a rigorous design for cause-andeffect predictions. They selected test sites on the basis of favorable ecological conditions and designed an active, iterative implementation procedure for interventions. Communication with stakeholders was one-directional in an information event on planned actions, which elicited resistance from farmers who feared flooding of their fields with pollutants by hindered runoff (I1:C2). The planning bureau representative confirmed that flooding by toxic sewage waters had happened previously several times (I2:C2). The district as well as the planning bureau representative considered the planned interventions causing such effects as worst-case scenarios $(\mathrm{I} 1: \mathrm{C} 1)$ and the perceived fears frequently exaggerated (I2:C2): Farmers "did not believe the numbers" (I2:C2) of the presented, calculated run-off estimations. "They say they know their waterways and those weird calculations that nobody understands are nonsense" (I2:C2).

Apart from expert knowledge, the managers in Case 2 also elicited lay-local knowledge about current water maintenance techniques at 169 rivers via questionnaires (Stiller and Trepel 2010). Altered riparian vegetation directly affected agricultural practices, therefore the managing biologist first sought permission by the umbrella organization of all water boards at federal state level, mostly constituted by landowners and farmers, and afterwards by five local water boards that agreed on collaborating at five test rivers. These were integrated into a rigorous design as parallel test 
Fig. 3. Phases of adaptive management projects with influencing factors and results found in the cases. Dark grey boxes refer to ecological uncertainty; light grey boxes to social uncertainty. The factors of bridging organizations, local scale, legal context, and reversibility are integrated into Table 2.

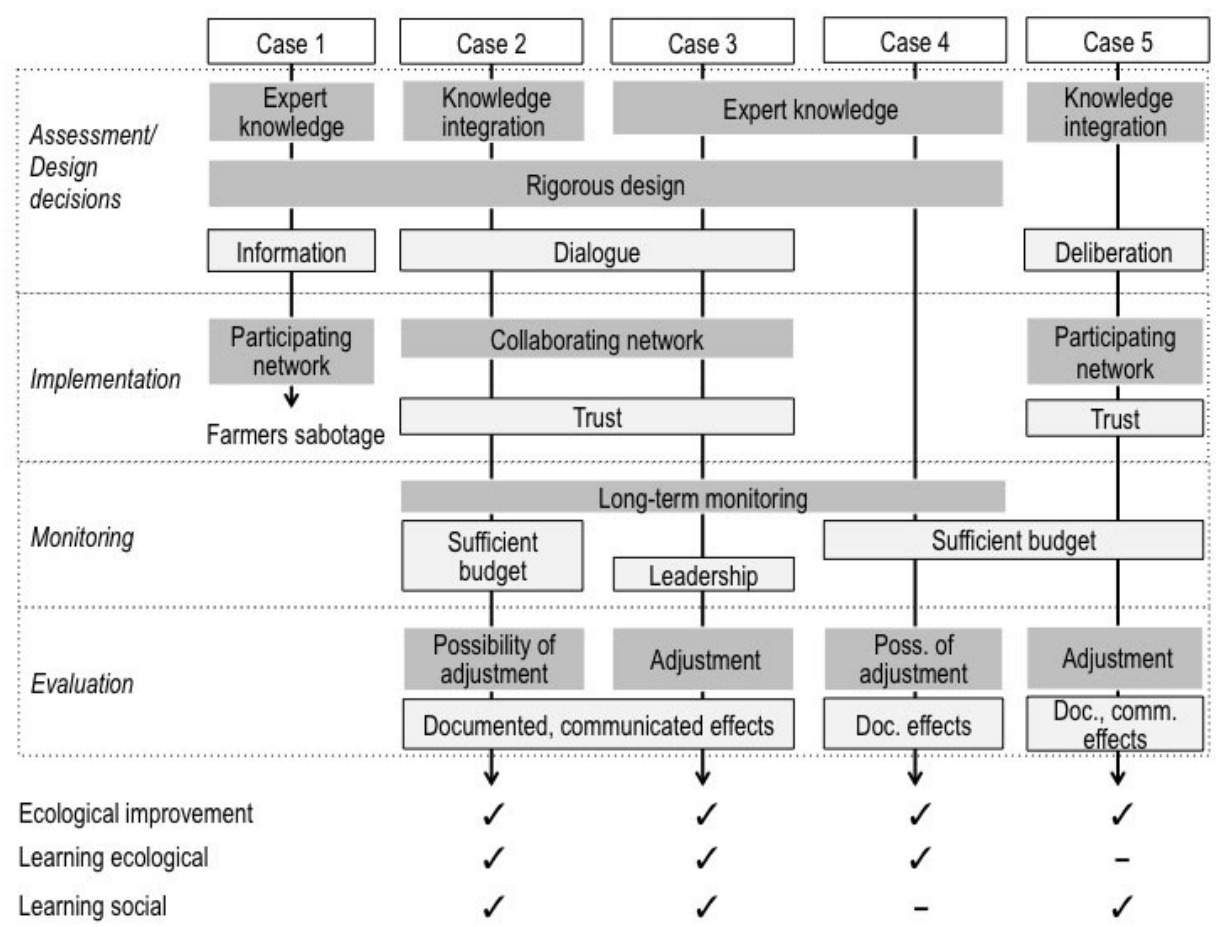

sites. Working plans for each of the five pilot river sites were agreed upon with these water boards in bilateral dialogue (Stiller 2014), which brought the project closer to a bounded experiment.

In Case 3 the university conducted flow measurements to construct a database and developed a rigorous, iterative testing design for in-stream modifications. Test sites were selected with agencies and deliberately chosen to lie in areas with low potential conflict, primarily not affecting agriculture. Managers and the only farmer renting land at one test river stretch agreed on the cautious implementation of only one action (I:C3). This test site selection was similar in Case 4 , where once more a rigorous, parallel testing design was developed based on expert knowledge such as the only existing review of water plants the interviewee knew of (I:C4).

In Case 5 the ENGO selected test sites mainly according to acceptance of stakeholders and agency representatives via bilateral talks and within two deliberative workshops with residents, recreational sport associations, anglers, and interested citizens (I1:C5, I2:C5). Apart from integrating local knowledge, planned interventions were presented and discussed with the possibility to bring in new proposals, and later put online for voting. The participants agreed on all actions and did not bring in new proposals for in-stream interventions, but contributed new ideas for implementation techniques (NABU 2013a,b). Although participants asked for a scientific backing because of the pilot character of test sites in the inner urban area (I1:C5), the ENGO did not develop a rigorous design.

\section{Implementation}

Despite the high disagreement of stakeholders, i.e., farmers, the fixed plan in Case 1 was not changed and no further communication took place. A network of ENGO volunteers, which did not include the affected farmers, implemented the actions. After the first implementation, a farmer sabotaged the project by dredging out all installed material during the night. The project came to a halt afterwards (I1, 2:C1).

In the first test phase on altered riparian vegetation of Case 2 new ideas from water boards and the leading biologist were constantly brought in (I:C2). The five water boards formed a small network that collaborated closely, bringing specific resources, such as excavator operators, and know-how to the project (Stiller 2014).

In Case 3 the university initiating the project opted out after the first round of implementation and monitoring because of an unexpected research project conclusion. The water board and particularly their biologist were keen on continuing the project, and took it over entirely (I:C3). They started a collaboration with the water and shipping administration and their trainees program through which a new flow measurement could be carried out serving as a new knowledge base (I:C3). Together they expanded their implementing network to additional agencies (Lübeck Port Authority; I:C3). The trainees developed and implemented the in-stream modifications through annual competitions, which led to innovative ideas according to the biologist (I:C3). The biologist also maintained a constant dialogue with stakeholders, such as anglers (I:C3). 
In Case 4 one stretch of the river of Case 1 had also been chosen as one of the four, parallel test-sites. During water plant installation the biologists were chased away by the same farmer who had sabotaged the project in Case 1, therefore they selected another test stretch further down the river in order to continue without drawing conflict from any stakeholders (I:C4).

In Case 5, the ENGO organized special days for implementation in which participants from the workshops, interested citizens, and other actors could participate (I1:C5; I2:C5). In addition, socalled creek partnerships, already established groups of residents, stakeholders, and interested citizens that look over certain river stretches in Hamburg, were always invited (I1:C5; I2:C5). Schools and companies could participate on demand (https://hamburg. nabu.de/natur-und-landschaft/gewaesser/18093.html; I2:C5). In comparison the network was ad-hoc and looser than in the other two cases, as the main aim seemed to be participation in implementation instead of shared and exchanged knowledge. Managers also upheld a constant dialogue with stakeholders (I2: C5). According to both interviewees in Case 5, early communication with agencies and stakeholders was crucial for implementation: "You have to talk to the people, then it's ok" (I1C:5) and "you first have to build up trust" (I2C:5). Trust building via early communication played a crucial role for understanding and acceptance in all cases with potentially affected stakeholders (Cases 2, 3, 5). Trust built between managers and stakeholders until implementation started supported this phase substantially through no disruptions of the experimental interventions or joint implementation. In contrast no trust was generated in Case 4, nor was it needed, because test sites were selected that did not generate any conflict with stakeholders.

\section{Monitoring}

Relying on sufficient funds by the federal state agency, the project managers in Case 2 carried out monitoring continuously and in the long term. It took place in the same month of three consecutive years (Stiller 2014) and four years later, showing the same results (I:C2).

In Case 3, the water board obtained new funding by the county, yet no resources for monitoring were foreseen, so the biologist started her own monitoring via photo documentation, supported by a local forester. They take photos at least once a year at the same position and from the same angle at various river sites: "This [the monitoring] is very important; without the assessment this is useless" (I:C3). Together with the adoption of the project management, the continuous, long-term monitoring over years implies substantial leadership by the water board and particularly the leading biologist in this case. In the other cases managers were all ambitious in delivering this phase, for instance also testing new monitoring practices in Case 5 according to the interviewee (which were not documented), but the voluntary action by the manager in Case 3 represented a vital element to maintain the delivery of this phase and the whole project, which we categorize therefore as leadership.

In Case 4 monitoring was carried out several times, two years apart and also three years later (I:C4). In Case 5 monitoring was carried out once at the end of the project at several points of the river (Hammer 2018). According to one ENGO representative, they already knew as much about effects that continuous monitoring was not necessary (I2:C5). In none of the cases did participatory monitoring take place; rather monitoring was directed by managers.

\section{Evaluation and adjustment}

In Case 2 adjustment was possible, yet actions were not adjusted, because they showed the anticipated results already in the initial and particularly final monitoring round. This case provided the most systematic documentation on effects, with comprehensive reports on the process of interventions and results (Stiller 2014). The results were communicated via training to water boards, ENGOs, and local administration.

In Case 3 iterative adjustments were employed to see how far river flows could be altered through in-stream modifications for achieving anticipated effects. The water board documented the process of in-stream modifications and provided a summary on its website. The photo monitoring was compared to initial measurements on flow and breadth of the rivers to detect erosion at riverbanks (DSV Rantzau 2017, unpublished data). This assessment was communicated to their collaborating network.

In Case 4, which had an experiment with parallel test-sites like Case 2, the monitoring round also showed that adjustments were not necessary. Documentation of effects was also systematic and contained practitioner instructions (Stiller and Engelschall 2014). No further communication of results occurred.

In Case 5, where iterative adjustments to in-stream modifications were applied, project managers held an annual event sharing the project's progress and results with Hamburg's water administration, ENGOs, and interested citizens. There is no overall evaluation and aggregated documentation planned in Case 5, yet all presentations held at these events are available online.

\section{Outcomes}

In all cases that completed at least one feedback cycle (Cases 2 , 3,4 , and 5), there was evidence of improved ecological results (see Fig. 4). In Case 2, the altered riparian vegetation and waterway management led to improved water quality without reducing runoff too far (Stiller 2014). In Case 3 it became clear what kind of meandering can be produced by which type of installed material (DSV Rantzau 2017, unpublished data). In Case 4 managers learned which type of cleaning water plants can be introduced best (Stiller and Engelschall 2014). In Case 5 the assessments even showed improved fish and invertebrates population (Hammer 2018).

Fig. 4. Outcomes of adaptive management projects.

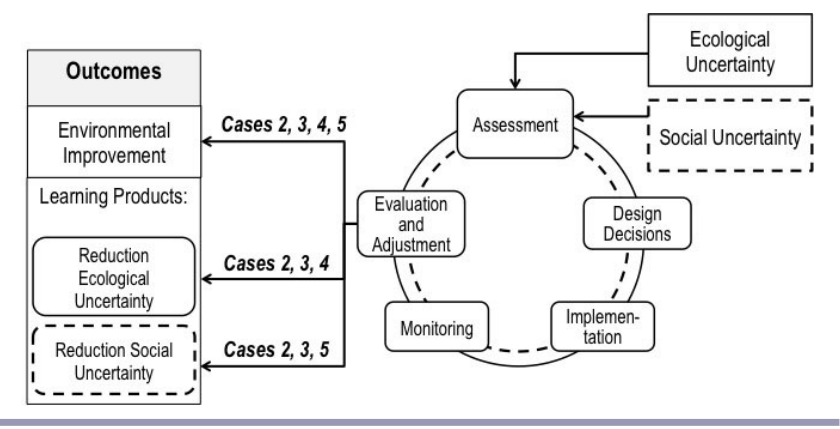


Regarding the learning products, the documentation of implementation techniques in Cases 2 to 4 indicate ecological learning by managers. In contrast, informants criticized the monitoring in Case 5, which precluded tracking of erosion or of blocked waterways by material that got washed away. "Several things can go wrong. ... One has to find middle ground between inspiring and activating a lot of people and doing it adequately for the waterway and everyone [affected]. This is difficult." (I:C2). Ecological uncertainty was not reduced substantially in this case.

In Cases 2, 3, and 5, learning about the social and organizational structures of the entire process was indicated. In Case 5, the process of involving stakeholders is documented (NABU 2013a, $b$ ), and an interviewee said the project showed "how far they can go with different stakeholders," and included a "steep learning curve" (I2:C5) in this regard. Cases 2 and 3 included no written documentation of how social factors were considered; therefore it is more complicated to identify learning about social uncertainty during the AM process. Nonetheless, managers in both cases continued with the strategies that appeared to have worked for the first project application. In Case 2 the new management practices were replicated with landowners and water boards at 37 rivers in Schleswig-Holstein, and afterward piloted in rivers in the neighboring federal states of Hamburg and Lower Saxony. The main manager in Case 2 involved landowners gradually via mediation and dialogue: “... You have to get to know their current position, ... even with the hardliners. ... One has to involve people slowly" (I:C1). She first targeted landowners with moderate positions, and organized training with a theory and praxis part on site. Likewise, the grown implementing network in Case 3 replicated the project at further river stretches. Managers once more deliberately sought acceptance of land-owning farmers by showing tested in-stream modifications, which had not affected riverbanks through erosion (I:C3).

Apart from the main managers, additional stakeholders learned in Cases 2 and 3. As the project replication in Case 2 shows, farmers adopted the ecologically more sensitive management of riparian and waterway vegetation. In Case 3, the trainees have replicated the project in cooperation with another water board at a considerably smaller waterway since 2017 (I:C3). The project manager confirmed: “... To take the project in [our] own hands has led to a learning effect of all participants" (I:C3). Regarding public officials, it was more difficult to trace learning. From the point of view of interviewed nonstate actors, the up-take of knowledge and actual application of know-how depends on the interest, time, or political considerations of the respective responsible public official (I2:C1, I:C4, I2:C5). Also the participating network in Case 5 showed no clear signs of learning. Some of the participants from the initial workshops participated in the "implementation days," yet, according to the interviewee the interest in ecological effects was usually not high (I2:C2).

It is worth noting that in Case 1, where implementation failed and the AM process did not complete a full cycle, nevertheless some social learning about how stakeholders will respond to interventions did occur. When asked about lessons learned, the district representative highlighted the importance to "built up trust with the actors on site" (I1:C1) and the planning bureau representative put emphasis on early information and transparency (I2:C1). Nonetheless, according to him "It's whether they [stakeholders] are affected [that matters]" (I2:C1).
In sum, Cases 2 to 5 achieved ecological improvement. However, learning about managing ecological uncertainties appeared to evolve to a lesser degree in Case 5, where the adaptive management design was less rigorous than in Cases 2, 3, and 4. In the cases that confronted social uncertainties (Cases 2, 3, 5), there were indications that managers learned how to deal with those. In the cases with a collaborating network and a rigorous design, participants of the network indicated learning about implementation techniques, i.e., managing ecological uncertainties, as they continued with the new management approaches by themselves in Case 2 or replicated the whole approach with new actors in Case 3.

\section{DISCUSSION}

The five examined AM cases exemplify important steps toward innovations in water management practices. Having examined all cases in detail, we discuss in the following which of the enabling factors outlined in the concepts played an important role for successful outcomes.

All cases with at least one full iteration of an AM cycle showed environmental improvement. Learning by managers about how to reduce ecological uncertainty was indicated in the cases that developed a rigorous experimental design, systematically incorporated new knowledge, and applied long-term monitoring as well as evaluation (Cases 2, 3, 4). The degree of learning about ecological uncertainty was lower in Case 5 with a less rigorous design. However, iterative adjustment of interventions made it also possible to achieve enhanced water quality in Case 5.

Interestingly, whether knowledge was gained via expert knowledge or the integration of different knowledge types appeared not to make a substantial difference for learning about the ecological effectiveness of measures, nor for environmental improvement. This supports McFadgen and Huitema (2017), who found that cognitive learning was higher in technocratic than in bounded experiments. However, in the cases in which knowledge was elicited from stakeholders or participants on actions and likely impacts the contributed knowledge ranged from helpful to very important. Networks beyond the case in hand learned about management approaches by adopting new techniques (Case 2) or even spreading the successful results by starting projects of their own (Case 3). The direct on-site involvement in implementation appeared to encourage learning by stakeholders, which corresponds to other studies on participation in water governance (Kochskämper et al. 2016, 2017).

Although involvement of stakeholders might not be a necessity for the reduction of ecological uncertainty, communicating with stakeholders was vital for dealing with social uncertainties through gaining trust and building a shared understanding to support the intervention. All experiments were conducted on a local scale and within the legal context of the WFD that fosters water quality enhancement, and they included easily reversible interventions, yet the reaction toward experiments varied. Particularly Case 1 and 2 seem telling in this context. Both cases included a bridging organization and in both cases management actions could slightly reduce run-off in the rivers crossing farmers' land. Trust built between managers and farmers in Case 2, through constant dialogue and mediation from early on, led to cooperation. Without this bond, understanding of information about the potential impact and thereby acceptance of interventions did not evolve in Case 1, leading to farmers 
sabotaging the experiment. Research shows that the sharing of information is a prerequisite for trust-building and effective collaboration (Pahl-Wostl 2009, Hurlbert and Gupta 2015, Kochskämper et al. 2017). Moreover, trust might be critical in situations of adaptive experimentation, which implies the possibility of failure; Kahneman and Tversky (1979) showed actors being more risk averse to potential future losses than gains. Understanding and processing of information might not be rational when potential future losses are perceived (Simon 1985), and requires therefore highly trusted sources.

The importance of communication also points to conflict as being part of an experimental approach (Lee 1993, 1999). Jacobson et al. (2006) found a lack of management flexibility to be one of the most challenging barriers for AM in a survey of U.S. agency staff. Gunderson (1999) identified a lack of flexibility in the social system, namely in the existent power relationships between stakeholders, to be one of the reasons for failure of active AM. However, following Voß and Bornemann (2011), political struggle and power dynamics are integral parts of policy-and governancerelated management, frequently overlooked in AM literature. The experiments in our cases were designed to affect agriculture, which is the main nitrate polluter, as little as possible, and nonetheless encountered resistance when the technocratic approach seemed detached from the social context. Managers learned not only about ecological but also social factors in the experiments under expert lead with stakeholder involvement (Cases 2, 3). The replication of the management approach with farmers (Case 2) or by administrative actors (Case 3 ) led to the spreading of the innovative practices, which can be seen as a first step toward the direction of double-loop learning. Last, social uncertainty about how stakeholders will respond to interventions includes both negative and positive surprises. An example of the latter is the continuation of the project in Case 3 by the water board following unexpected closure of funding and leadership by the managing biologist.

Taken together, the factors identified by literature for the success of AM projects played an important role in the indicated management phases throughout these cases. Only bridging organizations and sufficient budget faded into the background, once other more important factors, such as trust and leadership, were missing or emerged. The cases show that factors can be distinguished regarding ecological and social uncertainty.

\section{CONCLUSION}

In this study, we explored five adaptive management (AM) projects on water quality enhancement, which led to innovations in the small-scale management of waterways in northern Germany. We clarified the core conceptual components of AM and found evidence of learning and environmental improvements through the approach.

On a conceptual level, our findings suggest the model of a dual feedback cycle, including management of both ecological and social uncertainty. The conceptual differentiation of uncertainties allows for a more clear-cut analysis of the approach: The cycle linked to social uncertainty about how stakeholders will respond to interventions was crucial for successful implementation of experimental interventions and project completion, while the cycle linked to ecological uncertainty about how ecosystems will respond to interventions was crucial for environmental improvement. The first one is arguably the prerequisite to keep the second running. All cases that considered both types of uncertainties and related factors succeeded in a full feedback cycle and in achieving environmental improvement in the rivers.

The importance of considering social alongside ecological uncertainty during AM might explain why Fabricius and Cundill (2014) found in a systematic review on completed AM projects the main documented learning to be about social factors rather than-as initially intended by projects-how management interventions impacted environmental improvement. Out of our cases, in the ones indicating learning about implementation techniques and the social and organizational structures of the entire process, results spread beyond the initial project and administrative boundaries more easily. These findings put learning about process design and delivery to achieve successful outcomes in the forefront in AM, similar in this sense to what Newig et al. (2016) have defined as governance learning.

Our study highlights the importance of stakeholders accepting experimental approaches. The cases reveal that even in a favorable political environment the concerns of stakeholders (actual or perceived) can jeopardize effective AM and require careful attention. Alongside institutional structures, and political commitment, particularly for monitoring (Butler and Koontz 2005), the low tolerance of uncertainties by stakeholders is a frequently overlooked point in AM literature (see Bijlsma et al. 2011 as a positive counterexample).

By adding social uncertainty about how stakeholders respond to experiments, we point to a need for AM to address both social and ecological aspects of what are, after all, social-ecological systems. This could also serve as a gateway to more fully incorporating other aspects of social systems into AM, for example, including experiments to learn about what factors affect individuals' behavior. If, for example, ecological experiments point to the value of specific riparian vegetation in improving water quality, we could also conduct policy experiments to learn which policy tools might shape landowners' behavior toward vegetation management.

Our study helps to fill the substantial gap in literature of empirical studies on implementation of AM projects and full iterations of the AM cycle. Four successful (of the five) cases are not sufficient for generalizations, particularly because of the specific type and context of experiments. The WFD context provided all the experiments with a high leeway as alternative management designs to achieve water quality enhancement, which cannot be assumed automatically for other policy experiments. The study is also limited by our focus on the main project managers and documentation material without additional interviews of stakeholders. Still, the in-depth approach allowed for a thorough exploration of case trajectories. The majority of factors identified as influential in the literature proved to play an important role in the cases, not all the time, but tied to specific phases of the management cycle as a response to both types of uncertainty. Some factors, such as trust and adjustment, stood out in this respect. Others showed unexpected results: Despite being widely assumed in literature to improve knowledge gain, successful ecological knowledge incorporation was not contingent on the integration of stakeholder knowledge. 
Although these findings can provide a more nuanced view on AM projects and results, it seems challenging to translate them from the local scale onto higher or multiple policy levels, as identified in the multilevel, polycentric, and collaborative context of adaptive governance (Walker et al. 2004, Folke et al. 2005, Folke 2006, Chaffin et al. 2014). Continuous collaboration in AM implementation at the local level fostered interactive learning and motivation building conducive to collective action, which is still a blank spot in the learning literature for adaptive governance (Berkes 2017). However, when more levels and actors come into the picture, sustaining multiactor collaboration in implementation becomes challenging, and anticipating degrees of effects for stakeholders through experimental approaches becomes increasingly complex. Social and political dynamics in general are more prominent in adaptive comanagement and adaptive governance literature (Voß and Bornemann 2011). Nonetheless, differentiating social and ecological uncertainty and related learning in these more complex settings might constitute an important venue for future research.

Responses to this article can be read online at: https://www.ecologyandsociety.org/issues/responses. php/12080

\section{Data Availability:}

The datalcode that support the findings of this study are available on request from the corresponding author, [E.K.]. The datalcode are not publicly available because they contain information that could compromise the privacy of research participants.

\section{LITERATURE CITED}

Aceves-Bueno, E., A. S. Adeleye, D. Bradley, W. T. Brandt, P. Callery, M. Feraud, K. L. Garner, R. Gentry, Y. Huang, I. McCullough, I. Pearlman, S. A. Sutherland, W. Wilkinson, Y. Yang, T. Zink, S. E. Anderson, and C. Tague. 2015. Citizen science as an approach for overcoming insufficient monitoring and inadequate stakeholder buy-in in adaptive management: criteria and evidence. Ecosystems 18:493-506. https://doi.org/10.1007/ s10021-015-9842-4

Allan, C., and G. H. Stankey. 2009. Adaptive environmental management: a practitioner's guide. Springer Science and CSIRO, Dordrecht, The Netherlands.

Allan, C., and R. J. Watts. 2018. Revealing adaptive management of environmental flows. Environmental Management 61:520-533. https://doi.org/10.1007/s00267-017-0931-3

Allen, C. R., J. J. Fontaine, K. L. Pope, and A. S. Garmestani. 2011. Adaptive management for a turbulent future. Journal of Environmental Management 92:1339-1345. https://doi.org/10.1016/ j.jenvman.2010.11.019

Allen, C. R., and A. S. Garmestani. 2015. Adaptive management. Pages 1-10 in C. R. Allen and A. S. Garmestani, editors. Adaptive management of social-ecological systems. Springer, Dordrecht, The Netherlands. https://doi.org/10.1007/978-94-017-9682-8 1
Argyris, C., and D. A. Schön. 1978. Organizational learning: a theory of action perspective. Addison-Wesley, Reading, UK.

Argyris, C., and D. Schön. 1996. Organizational learning II: theory, method, and practice. Addison-Wesley, Reading, UK.

Armitage, D., M. Marschke, and R. Plummer. 2008. Adaptive comanagement and the paradox of learning. Global Environmental Change 18:86-98. https://doi.org/10.1016/j.gloenvcha.2007.07.002

Armitage, D., R. Plummer, F. Berkes, R. I. Arthur, A. T. Charles, I. J. Davidson-Hunt, A. P. Diduck, N. C. Doubleday, D. S. Johnson, M. Marschke, P. McConney, E. W. Pinkerton, and E. K. Wollenberg. 2009. Adaptive co-management for socialecological complexity. Frontiers in Ecology and the Environment 7(2):95-102. https://doi.org/10.1890/070089

Berkes, F. 2017. Environmental governance for the Anthropocene? Social-ecological systems, resilience, and collaborative learning. Sustainability 9(7):1232. https://doi. org/10.3390/su9071232

Berkley, J., and L. Gunderson. 2015. Practical resilience: building networks of adaptive sanagement. Pages 201-216 in C. Allen and A. Garmestani, editors. Adaptive management of social-ecological systems. Springer, Dordrecht, The Netherlands. https://doi. org/10.1007/978-94-017-9682-8 11

Bijlsma, R. M., P. W. G. Bots, H. A. Wolters, and A. Y. Hoekstra. 2011. An empirical analysis of stakeholders' influence on policy development: the role of uncertainty handling. Ecology and Society 16(1):51. https://doi.org/10.5751/es-03865-160151

Blackmore, C., S. van Bommel, A. de Bruin, J. de Vries, L. Westberg, N. Powell, N. Foster, K. Collins, P. P. Roggero, and G. Seddaiu. 2016. Learning for transformation in water governance: reflections on design from the climate change adaptation and water governance (CADWAGO) Project. Water 8(11):510. https://doi.org/10.3390/w8110510

Butler, K., and T. Koontz. 2005. Theory into practice: implementing ecosystem management objectives in the USDA Forest Service. Environmental Management 35:138-150. https:// doi.org/10.1007/s00267-003-0312-y

Chaffin, B., and H. Gosnell. 2015. Measuring success of adaptive management projects. Pages 85-105 in C. Allen and A. Garmestani, editors. Adaptive management of social-ecological systems. Springer, Dordrecht, The Netherlands. https://doi. org/10.1007/978-94-017-9682-8_6

Chaffin, B. C., H. Gosnell, and B. A. Cosens. 2014. A decade of adaptive governance scholarship: synthesis and future directions. Ecology and Society 19(3):56. https://doi.org/10.5751/ES-06824-190356

Cook, W. M., D. G. Casagrande, D. Hope, P. M. Groffman, and S. L. Collins. 2004. Learning to roll with the punches: adaptive experimentation in human-dominated systems. Frontiers in Ecology and the Environment 2(9):467-474. https://doi. org/10.1890/1540-9295(2004)002[0467:LTRWTP]2.0.CO;2

de Groot, W. T., and H. J. R. Lenders. 2006. Emergent principles for river management. Hydrobiologia 565:309-316. https://doi. org/10.1007/s10750-005-1921-7 
Fabricius, C., and G. Cundill. 2014. Learning in adaptive management: insights from published practice. Ecology and Society 19(1):29. https://doi.org/10.5751/ES-06263-190129

Fabricius, C., and B. Currie. 2015. Adaptive co-management. Pages 147-179 in C. Allen and A. Garmestani, editors. Adaptive management of social-ecological systems. Springer, Dordrecht, The Netherlands. https://doi.org/10.1007/978-94-017-9682-8 9

Folke, C. 2006. Resilience: the emergence of a perspective for social-ecological systems analyses. Global Environmental Change 16:253-267. https://doi.org/10.1016/j.gloenvcha.2006.04.002

Folke, C., T. Hahn, P. Olsson, and J. Norberg. 2005. Adaptive governance of social-ecological systems. Annual Review of Environmental Resources 30:441-473. https://doi.org/10.1146/ annurev.energy.30.050504.144511

Foxon, T. J., M. S. Reed, and L. C. Stringer. 2009. Governing long-term social-ecological change: what can the adaptive management and transition management approaches learn from each other? Environmental Policy and Governance 19:3-20. https:// doi.org/10.1002/eet.496

Gerring, J. 2007. Case study research: principles and practices. Cambridge University Press, New York, New York, USA.

Graham, N. A. J., and C. C. Hicks. 2015. Adaptive management for novel ecosystems. Pages 123-146 in C. Allen and A. Garmestani, editors. Adaptive management of social-ecological systems. Springer, Dordrecht, The Netherlands. https://doi. org/10.1007/978-94-017-9682-8 8

Gregory, R., L. Failing, and P. Higgins. 2006. Adaptive management and environmental decision making: a case study application to water use planning. Ecological Economics 58:434-447. https://doi.org/10.1016/j.ecolecon.2005.07.020

Gunderson, L. 1999. Resilience, flexibility and adaptive management - -antidotes for spurious certitude? Conservation Ecology 3(1):7. https://doi.org/10.5751/es-00089-030107

Gunderson, L. 2015. Lessons from adaptive management: obstacles and outcomes. Pages 27-38 in C. Allen and A. Garmestani, editors. Adaptive management of social-ecological systems. Springer, Dordrecht, The Netherlands. https://doi. org/10.1007/978-94-017-9682-8 3

Gunderson, L., and C. S. Holling. 2002. Panarchy: understanding transformations in human and natural systems. Island, Washington, D.C., USA.

Hahn, T., P. Olsson, C. Folke, and K. Johansson. 2006. Trustbuilding, knowledge generation and organizational innovations: the role of a bridging organization for adaptive co-management of a wetland landscape around Kristianstad, Sweden. Human Ecology 34:573-592. https://doi.org/10.1007/s10745-006-9035-Z

Hammer, W. 2018. Ergebnisse und Entwicklungen der bisherigen Maßnahmen an der Alster [Results and developments of the implemented measures at the Alster]. Lebendige Alster, Hamburg, Germany. [online] URL: https://www.lebendigealster. de/app/download/7609190764/180605 Ergebnisse+und+

Entwicklungen_AL.pdf?t=1540374133

Hering, D., A. Borja, J. Carstensen, L. Carvalho, M. Elliott, C. K. Feld, A. S. Heiskanen, R. K. Johnson, J. Moe, D. Pont, A. L.
Solheim, and W. van de Bund. 2010. The European Water Framework Directive at the age of 10: a critical review of the achievements with recommendations for the future. Science of the Total Environment 408:4007-4019. https://doi.org/10.1016/j. scitotenv.2010.05.031

Hillmann, M. 2009. Integrating knowledge: the key challenge for a new paradigm in river management. Geography Compass 3 (6):1988-2010. https://doi.org/10.1111/j.1749-8198.2009.00278.x

Holling, C. S. 1978. Adaptive environmental assessment and management. Wiley, Chichester, UK.

Holling, C. S., and S. M. Sundstrom. 2015. Adaptive management, a personal history. Pages 11-25 in C. Allen and A. Garmestani, editors. Adaptive management of social-ecological systems. Springer, Dordrecht, The Netherlands. https://doi. org/10.1007/978-94-017-9682-8 2

Huitema, D., E. Mostert, W. Egas, S. Moellenkamp, C. PahlWostl, and R. Yalcin. 2009. Adaptive water governance: assessing the institutional prescriptions of adaptive (co-)management from a governance perspective and defining a research agenda. Ecology and Society 14(1):26. https://doi.org/10.5751/ES-02827-140126

Hurlbert, M., and J. Gupta. 2015. The split ladder of participation: a diagnostic, strategic, and evaluation tool to assess when participation is necessary. Environmental Science \& Policy 50:100-113. https://doi.org/10.1016/j.envsci.2015.01.011

Jacobson, C., K. F. D. Hughey, W. J. Allen, S. Rixecker, and R. W. Carter. 2009. Toward more reflexive use of adaptive management. Society \& Natural Resources 22(5):484-495. https:// doi.org/10.1080/08941920902762321

Jacobson, S. K., J. K. Morris, J. S. Sanders, E. N. Wiley, M. Brooks, R. E. Bennetts, H. F. Percival, and S. Marynowski. 2006. Understanding barriers to implementation of an adaptive land management program. Conservation Biology 20:1516-1527. https://doi.org/10.1111/j.1523-1739.2006.00476.x

Kahneman, D., and A. Tversky. 1979. Prospect theory: an analysis of decision under risk. Econometrica 47(2):263-292. https://doi. org/10.2307/1914185

Keith, D. A., T. G. Martin, E. McDonald-Madden, and C. Walters. 2011. Uncertainty and adaptive management for biodiversity conservation. Biological Conservation 144:1175-1178. https://doi.org/10.1016/j.biocon.2010.11.022

Kochskämper, E., E. Challies, N. W. Jager, and J. Newig. 2017. Participation for effective environmental governance: evidence from European Water Framework Directive implementation. Routledge, London, UK. https://doi.org/10.4324/9781315193649

Kochskämper, E., E. Challies, J. Newig, and N. W. Jager. 2016. Participation for effective environmental governance? Evidence from Water Framework Directive implementation in Germany, Spain and the United Kingdom. Journal of Environmental Management 181:737-748. https://doi.org/10.1016/j.jenvman.2016.08.007

Koontz, T. M., D. Gupta, D. Mudliar, and P. Ranjan. 2015. Adaptive institutions in social-ecological systems governance: a synthesis framework. Environmental Science and Policy 53:139-151. https://doi.org/10.1016/j.envsci.2015.01.003 
Koontz, T. M., and T. W. Thomas. 2006. What do we know and need to know about the environmental outcomes of collaborative management? Public Administration Review 66(1):111-121. https://doi.org/10.1111/j.1540-6210.2006.00671.x

Lamnek, S. 1989. Qualitative Sozialforschung. Band 2: Methoden und Techniken. Beltz, Weinheim, Germany.

Lee, K. N. 1993. Compass and gyroscope: integrating science and politics for the environment. Island, Washington, D.C., USA.

Lee, K. N. 1999. Appraising adaptive management. Conservation Ecology 3(2):3. https://doi.org/10.5751/ES-00131-030203

McFadden, J. E., T. L. Hiller, and A. J. Tyre. 2011. Evaluating the efficacy of adaptive management approaches: Is there a formula for success? Journal of Environmental Management 92:1354-1359. https://doi.org/10.1016/j.jenvman.2010.10.038

McFadgen, B., and D. Huitema. 2017. Stimulating learning through policy experimentation: a multi-case analysis of how design influences policy learning outcomes in experiments for climate adaptation. Water 9(9):648. https://doi.org/10.3390/ w9090648

Medema, W., B. S. McIntosh, and P. J. Jeffrey. 2008. From premise to practice: a critical assessment of integrated water resources management and adaptive management approaches in the water sector. Ecology and Society 13(2):29. https://doi.org/10.5751/ ES-02611-130229

Meffe, G. K., L. A. Nielsen, R. L. Knight, and D. A. Schenborn. 2002. Ecosystem management: adaptive, community-based conservation. Island, Washington, D.C., USA.

Miles, B. M., and A. M. Huberman. 1994. Qualitative data analysis. An expanded sourcebook. SAGE, Thousand Oaks, California, USA.

Murray, C. L., D. R. Marmorek, and L. A. Greig. 2015. Adaptive management today: a practitioners' perspective. Pages 181-199 in C. Allen and A. Garmestani, editors. Adaptive management of social-ecological systems. Springer, Dordrecht, The Netherlands. https://doi.org/10.1007/978-94-017-9682-8 10

NABU (Naturschutzbund Deutschland). 2013a. Protokoll der 2. Werkstatt im Beteiligungsprozess für eine "Lebendige Alster." NABU, Hamburg, Germany. [online] URL: https://www. lebendigealster.de/app/download/5787460564/130425_LA_Werkstatt2 Protokoll.pdf?t=1491657316

NABU (Naturschutzbund Deutschland). 2013b. Protokoll der 1. Werkstatt im Beteiligungsprozess für eine "Lebendige Alster." NABU, Hamburg, Germany. [online] URL: https://www. lebendigealster.de/app/download/5752774964/130201_Lebendige Alster Protokoll Werkstatt1.pdf?t=1491657316

Newig, J., E. Challies, N. W. Jager, E. Kochskämper, and A. Adzersen. 2018. The environmental performance of participatory and collaborative governance: a framework of causal mechanisms. Policy Studies Journal 46(2):269-297. https://doi. org/10.1111/psj.12209

Newig, J., E. Kochskämper, E. Challies, and N. W. Jager. 2016. Exploring governance learning: how policymakers draw on evidence, experience and intuition in designing participatory flood risk planning. Environmental Science \& Policy 55:353-360. https://doi.org/10.1016/j.envsci.2015.07.020

O'Donnell, T. K., and D. L. Galat. 2008. Evaluating success criteria and project monitoring in river enhancement within an adaptive management framework. Environmental Management 41:90-105. https://doi.org/10.1007/s00267-007-9010-5

Pahl-Wostl, C. 2009. A conceptual framework for analysing adaptive capacity and multi-level learning processes in resource governance regimes. Global Environmental Change 19:354-365. https://doi.org/10.1016/j.gloenvcha.2009.06.001

Pahl-Wostl, C., J. Sendzimir, P. Jeffrey, J. Aerts, G. Berkamp, and K. Cross. 2007. Managing change toward adaptive water management through social learning. Ecology and Society 12 (2):30. https://doi.org/10.5751/es-02147-120230

Pahl-Wostl, C., J. Newig, and D. Ridder. 2008. Linking public participation to adaptive management. Pages 150-173 in $\mathrm{P}$. Quevauville, editor. Groundwater science and policy: an international overview. RSC Publishing, Cambridge, UK. https:// doi.org/10.1039/9781847558039-00150

Pahl-Wostl, C., J. Sendzimir, P. Jeffrey, J. Aerts, G. Berkamp, and K. Cross. 2007. Managing change toward adaptive water management through social learning. Ecology and Society 12 (2):30. https://doi.org/10.5751/ES-02147-120230

Plummer, R. 2009. The adaptive co-management process: an initial synthesis of representative models and influential variables. Ecology and Society 14(2):24. https://doi.org/10.5751/ES-03130-140224

Plummer, R., B. Crona, D. R. Armitage, P. Olsson, M. Tengö, and O. Yudina. 2012. Adaptive comanagement: a systematic review and analysis. Ecology and Society 17(3):11. https://doi. org/10.5751/ES-04952-170311

Pulwarty, R. S., and T. S. Melis. 2001. Climate extremes and adaptive management on the Colorado River: lessons from the 1997-1998 ENSO event. Journal of Environmental Management 63(3):307-324. https://doi.org/10.1006/jema.2001.0494

Rist, L., A. Felton, L. Samuelsson, C. Sandström, and O. Rosvall. 2013. A new paradigm for adaptive management. Ecology and Society 18(4):63. https://doi.org/10.5751/ES-06183-180463

Simon, H. A. 1985. Human nature in politics: the dialogue of psychology with political science. American Political Science Review 79(2):293-304. https://doi.org/10.2307/1956650

Stiller, G. 2014. Erfolgskontrolle Gewässerunterhaltung. Endbericht - Ergebnisse 2009-2013. Landesverband der Wasserund Bodenverbände Schleswig-Holstein (LWBV), Westerrönfeld, Germany.

Stiller, G., and B. Engelschall. 2014. Wiederansiedlung von Wasserpflanzen in Hamburger Fließgewässer. Praktische Handlungsempfehlungen. Botanischer Verein zu Hamburg e. V., Hamburg, Germany.

Stiller, G., and M. Trepel. 2010. Effects of stream management on the diversity and ecological status of aquatic macrophyte communities in rivers of Schleswig-Holstein. Zeitschrift für Naturschutz und Landschaftspflege 85(6):239-244. 
Stringer, L. C., A. J. Dougill, E. Fraser, K. Hubacek, C. Prell, and M. S. Reed. 2006. Unpacking "participation" in the adaptive management of social-ecological systems: a critical review. Ecology and Society 11(2):39. https://doi.org/10.5751/es-01896-110239

Thomas, K., and S. Allen. 2006. The learning organisation: a meta-analysis of themes in literature. Learning Organization 13 (2):123-139. https://doi.org/10.1108/09696470610645467

Tyre, A. J., and S. Michaels. 2011. Confronting socially generated uncertainty in adaptive management. Journal of Environmental Management 92(5):1365-1370. https://doi.org/10.1016/j. jenvman.2010.10.014

Voß, J. P., and B. Bornemann. 2011. The politics of reflexive governance: challenges for designing adaptive management and transition management. Ecology and Society 16(2):9. https://doi. org/10.5751/es-04051-160209

Walker, B., C. S. Holling, S. R. Carpenter, and A. Kinzig. 2004. Resilience, adaptability and transformability in social-ecological systems. Ecology and Society 9(2):5. https://doi.org/10.5751/ ES-00650-090205

Walters, C. J. 1986. Adaptive management of renewable resources. McGraw Hill, New York, New York, USA.

Walters, C. J. 1997. Challenges in adaptive management of riparian and coastal ecosystems. Conservation Ecology 1(2):1. https://doi.org/10.5751/ES-00026-010201

Walters, C. J., and C. S. Holling. 1990. Large-scale management experiments and learning by doing. Ecology 71(6):2060-2068. https://doi.org/10.2307/1938620

Waylen, K. A., and K. L. Blackstock. 2017. Monitoring for adaptive management or modernity: lessons from recent initiatives for holistic environmental management. Environmental Policy and Governance 27(4):311-324. https://doi.org/10.1002/ $\underline{\text { eet. } 1758}$

Williams, B. K., and E. D. Brown. 2014. Adaptive management: from more talk to real action. Environmental Management 53:465-479. https://doi.org/10.1007/s00267-013-0205-7

Williams, B. K., and E. D. Brown. 2016. Technical challenges in the application of adaptive management. Biological Conservation 195:255-263. https://doi.org/10.1016/j.biocon.2016.01.012 